\title{
Prevalence and treatment of giardiasis in chronic diarrhoea and malnutrition
}

P B Sullivan, M N Marsh, M B Phillips, O Dewit, G Neale, A M Cevallos, P Yamson, M J G Farthing

\begin{abstract}
To determine the prevalence of giardiasis in Gambian children with chronic diarrhoea and to assess their response to treatment, 31 children with chronic diarrhoea and malnutrition were investigated for giardiasis using a combination of serology (specific antigiardia IgM antibody) and microscopy of faeces and jejunal biopsy specimens. Fourteen of 31 children with chronic diarrhoea had giardiasis compared with only four of $\mathbf{3 3}$ healthy age and sex matched control children. Four of $15 \mathrm{mal}$ nourished children without diarrhoea were giardia positive. Twenty three children with chronic diarrhoea were reinvestigated after treatment with metronidazole; giardia was found in 11 of them. These results show that giardia is highly prevalent in children with chronic diarrhoea and malnutrition and that the infection does not respond to standard therapeutic measures.
\end{abstract}

Infection with Giardia lamblia is a recognised cause of chronic diarrhoea and malabsorption in children and may be associated with growth retardation. ${ }^{12}$ High prevalence rates for giardia infection have been reported in children in developing countries even if they are asymptomatic. $^{1-4}$ Diagnosis of giardiasis is usually based on microscopic identification of either trophozoites or cysts in faeces, but this method is unreliable and may miss many cases. ${ }^{56}$ Diagnostic precision can be improved by microscopic examination of duodenal aspirate, ${ }^{6}$ endoscopic brushings, ${ }^{7}$ or intestinal mucosa. ${ }^{8}$ To circumvent these invasive techniques, serological methods have been developed. ${ }^{9}$

Giardia infection leads to a prolonged specific antigiardia IgG response that lasts for many weeks or months; it is therefore unreliable in the diagnosis of the acute infection. Specific antigiardia IgM, however, is a much better indicator of acute infection. We have developed a serum antigiardia IgM enzyme linked immunosorbent assay (ELISA) as a diagnostic test for giardiasis with a sensitivity and specificity of $96 \%{ }^{9}$ Giardiasis can persist for many months in children who are malnourished and immunocompromised. There have, however, been no prospective studies of the impact of nutritional rehabilitation on the response to treatment of giardiasis in children with protein energy malnutrition.

The aims of this study were to find out the prevalence of giardiasis in a group of children with chronic diarrhoea and malnutrition in The Gambia, West Africa, and to assess the response to antigiardial treatment in children being treated for chronic diarrhoea and malnutrition.

\section{Subjects and methods}

The study was undertaken at the Medical Research Council's station in The Gambia, West Africa in children aged 6 to 36 months with chronic diarrhoea-malnutrition syndrome. This is defined as more than three loose stools/ day persisting for more than two weeks and severe protein energy malnutrition (defined as weight for height of $<75 \%$ of the National Center for Health Statistics median value). These patients (table 1) were recruited from the outpatient department and compared with age and sex matched control subjects comprising a group of well grown asymptomatic children (healthy controls) and a further group of children with protein energy malnutrition but with no history of diarrhoea (marasmic controls). Control subjects were recruited from the same geographical location as the patients with diarrhoea. While they were inpatients, all children with chronic diarrhoea malnutrition syndrome received empirical treatment with chloramphenicol $75-200 \mathrm{mg} / \mathrm{kg} /$ day and metronidazole $25 \mathrm{mg} / \mathrm{kg} /$ day for seven days.

Giardia trophozoites and cysts were sought by wet film microscopy of three consecutive fresh stool specimens (without concentration) collected before any treatment was started. There is evidence that this technique will detect giardia as reliably as concentrates. ${ }^{10}$ In addition to standard stool microscopy, antigiardia IgM titres were determined by an ELISA and a specific antigiardia IgM antibody titre of $1: 800$ or more was taken to indicate active giardia infection. ${ }^{9}$ The third diagnostic procedure in children with chronic diarrhoea malnutrition

Table 1 Demographic and nutritional data on 31 children with chronic diarrhoea and 48 controls

\begin{tabular}{llll}
\hline & $\begin{array}{l}\text { Children } \\
\text { with } \\
\text { chronic } \\
\text { diarrhoea } \\
(n=31)\end{array}$ & $\begin{array}{l}\text { Healthy } \\
\text { controls } \\
(n=33)\end{array}$ & $\begin{array}{l}\text { Marasnic } \\
\text { controls } \\
(n=15)\end{array}$ \\
\hline $\begin{array}{l}\text { Mean (range) age } \\
\text { (months) }\end{array}$ & $\begin{array}{l}19 \cdot 0(6-31) \\
15: 16\end{array}$ & $\begin{array}{l}16 \cdot 5(8-26) \\
20: 13\end{array}$ & $\begin{array}{l}14 \cdot 2(6-24) \\
8: 7\end{array}$ \\
$\begin{array}{l}\text { Male:female ratio } \\
\text { Weight for height* }\end{array}$ & $\begin{array}{l}15: 6(50-88) \\
88 \cdot 7(68-104)\end{array}$ & $63 \cdot 1(46-85)$ \\
$\begin{array}{l}\text { Residential area: } \\
\text { Urban }\end{array}$ & 11 & 12 & 3 \\
Rural & 20 & 21 & 12 \\
\hline
\end{tabular}

Expressed as mean (range) percentage of the National Center for Health Statistics median value.
Vincent Square,

London SWIP' 2NS
incent Square,

Accepted 1 November 1990 
syndrome and marasmic controls, was the identification of giardia trophozoites in sections of small bowel mucosa. Jejunal biopsy specimens were taken from the duodenojejunal junction with a modified, infant double port Crosby capsule that was introduced through the pylorus under direct vision with a paediatric fibreoptic endoscope. " Diagnosis of giardía infection was based on positive microscopic identification of the organism in faeces or in sections of intestinal mucosa or positive antigiardia IgM serology, or both.

About three weeks after admission, 23 patients with chronic diarrhoea malnutrition syndrome underwent repeat serology before discharge from the ward; a second jejunal biopsy specimen was taken from 20 of these children. Seven of 31 patients who had initially been treated for chronic diarrhoea malnutrition syndrome were readmitted 12 months later for clinical and microbiological assessment and further biopsy of the small intestine.

The $\chi^{2}$ test was used to assess the significance of differences between the prevalence of giardia infection in children with chronic diarrhoea and the control groups. Ethical approval for the study protocol was obtained from the committee on human experimentation of the Medical Research Council Tropical Research Unit, The Gambia. Patients were admitted to the study only after informed parental consent had been obtained through an interpreter.

\section{Results}

Giardiasis was diagnosed in 14 of 31 children with chronic diarrhoea malnutrition syndrome $(45 \%)$ compared with four of $33(12 \%)$ healthy $(p<0.008)$ and four of $15(27 \%)$ marasmic controls $(p=0.38)$ (table 2). Twenty three of 31 children with chronic diarrhoea malnutrition syndrome were investigated again three weeks later after treatment with antibiotics. A positive diagnosis of giardiasis was made in 11 of 23 $(48 \%)$, in 10 of them by identification of the parasite on the intestinal mucosa. At follow up one year later, of seven children who underwent repeat jejunal biopsy the parasite was identified on the intestinal mucosa in six (86\%). Four of these seven children were still malnourished; of the three who were not (mean weight for height $81 \%$ ) all had giardiasis.

Table 2 Prevalence of giardiasis in 31 children with chronic diarrhoea and $\mathbf{4 8}$ controls

\begin{tabular}{llll}
\hline & $\begin{array}{l}\text { Children } \\
\text { with } \\
\text { chronic } \\
\text { diarrhoea } \\
(n=31)\end{array}$ & $\begin{array}{l}\text { Healthy } \\
\text { controls } \\
(n=33)\end{array}$ & $\begin{array}{l}\text { Marasmic } \\
\text { controls } \\
(n=15)\end{array}$ \\
\hline $\begin{array}{l}\text { No (\%) with giardiasis } \\
\text { Giardia trophozoites } \\
\text { or cysts (or both) } \\
\text { identified in faeces } \\
\text { or jejunal mucosal } \\
\text { biopsy specimen }\end{array}$ & 11 & $4(12)$ & $4(27)$ \\
$\begin{array}{l}\text { Specific antigiardia } \\
\text { IgM titre ₹1:800 }\end{array}$ & 12 & 4 & \\
$\begin{array}{l}\chi^{2} \text { test (comparing } \\
\text { children with } \\
\text { diarrhoea with } \\
\text { each control group) }\end{array}$ & - & 1 & 3 \\
p Value & - & 7.07 & 0.78 \\
\hline
\end{tabular}

\section{Discussion}

The results of this controlled study have shown that there is an increased prevalence of $G \operatorname{lamb}$ lia infection in children with chronic diarrhoea malnutrition syndrome, and emphasise the potential importance of this organism in the pathogenesis of chronic diarrhoea. Furthermore, the results after a three week follow up period show that treatment of giardiasis with the recommended dose of metronidazole failed to eradicate the infection.

There are a number of possible explanations for this. Firstly, the patients may have become rapidly reinfected while in hospital by contact with other carriers. ${ }^{12}$ Secondly, the treatment regimen with metronidazole may be ineffective in patients with depressed immunity and, as reported elsewhere, these particular patients with chronic diarrhoea malnutrition syndrome were all anergic on intradermal challenge with standard recall antigens. ${ }^{13}$ Giardiasis is more common and lasts longer in patients who are malnourished and therefore immunocompromised, and this may account for persistent infection in children with chronic diarrhoea malnutrition syndrome, and the high prevalence rates among those control patients with 'pure' malnutrition (that is, without coexistent diarrhoea). ${ }^{14-16}$ Malnutrition, however, did not seem to be a factor in the small number of patients seen a year later, when half the children with giardiasis were not malnourished.

In addition to the immune system other host defences, including the gastric acid barrier, ${ }^{17}$ are impaired in protein energy malnutrition. Achlorhydria and hypochlorhydria are associated with an increased risk of giardiasis, and over a half of patients with symptomatic giardiasis have reduced gastric acid secretion. ${ }^{18} \mathrm{We}$ have also shown that this group have a high prevalence of gastric infection with Helicobacter pylori, ${ }^{19}$ an organism known to be associated with hypochlorhydria. ${ }^{20}$ Whether eradication of $H$ pylori from the stomach would prevent rapid reinfection with giardia after treatment of patients in endemic areas is unknown, but merits further investigation.

Assessment of the background prevalence of giardiasis in well grown, asymptomatic children in developing countries varies among studies and is dependent on selection criteria of subjects and methods of diagnosis. The healthy control children for this study were drawn from closely monitored communities for which reliable health and growth records were available, ${ }^{21}$ and where the lower prevalence rate $(12 \%)$ for giardia infection is likely to be a more accurate estimate than that reported elsewhere $\left(22 \%,{ }^{1}\right.$ $21 \%,{ }^{3}$ and $19 \%{ }^{4}$ ) and in which 'healthy' children may have included some with recent diarrhoea.

Although the dose of metronidazole that we used was that recommended for children, it is possible that more effective clearance of the organism might have occurred had a higher dose (for example, $35 \mathrm{mg} / \mathrm{kg} /$ day) been given for 10 days. The value of primary eradication of giardia in children with chronic diarrhoea needs to be assessed as does the value of a repeat course of treatment after nutritional rehabilita- 
tion and restoration of normal immune function.

The authors thank Dr Brian M Greenwood CBE, Director of the Medical Research Council Laboratories, Fajara, The Gambia for the provision of facilities and also the medical and nursing staff of the provision of facilities and also the medical and nursing staff of
the unit for their cooperation. We give particular thanks to our the unit for their cooperation. We give particular thanks to our
field worker Miss Oumie Jabang. This project was sponsored by field worker Miss Oumie Jabang. This project was sponsored by
the Thrasher Research Fund (Salt Lake City, Utah) whose generthe Thrasher Research Fund (Salt Lake City, Utah) whose gener-
osity and keen interest in the work are acknowledged. Dr Farthosity and keen interest in the work are acknowledged. Dr Farth-
ing was Wellcome Trust senior lecturer, and acknowledges the financial support of the Trust.

1 Mata LJ. The children of Santa Maria Cauqué: a prospective field study of health and growth. Cambridge, Mass: MIT Press, 1978.

2 Farthing MJG, Mata L, Urrutia JJ, Kronmal RA. Natural history of giardia infection of infants and children in rural history of giardia infection of infants and children in rural Guatemala and its impact
Nutr $1986 ; 43: 393-405$.

3 Gilman RH, Brown KH, Visvesvara GS, et al. Epidemiology and serology of Giardia lamblia in a developing country: Bangladesh. Trans $R$ Soc Trop Med Hyg 1985;79:469-73.

4 Mason PR, Patterson BA. Epidemiology of Giardia lamblia infection in children: cross-sectional and longitudinal studies in urban and rural communities in Zimbabwe. $A m \mathcal{F}$ Trop Med Hyg 1987;37:277-82.

5 Danciger $M$, Lopez $M$. Numbers of giardia in the feces of infected children. Am 7 Trop Med Hyg 1975;24:237-42.

6 Goka AKJ, Rolston DDK, Mathan VI, Farthing MJG. The relative merits of faecal and duodenal juice microscopy in the diagnosis of giardiasis. Trans $R$ Soc Trop Med Hyg 1990; 84:66-7.

7 Bendig DW. Diagnosis of giardiasis in infants and children by endoscopic brush cytology. I Pediatr Gastroenterol Nutr 1989;8:204-6.

8 Kamath KR, Murugasu RA. A comparative study of four methods for detecting Giardia lamblia in children with 66:16-21.
9 Goka AKJ, Rolston DDK, Mathan VI, Farthing MJG. Diagnosis of giardiasis by specific IgM antibody enzyme Diagnosis of giardiasis by specific IgM antibody en
linked immunosorbent assay. Lancet 1986;ii:184-6.

10 Gibb AP. Identification of unsuspected cases of giardiasis by wet film microscopy. Lancet 1989;ii:216-7.

11 Sullivan PB, Phillips MB, Neale G. Endoscopic capsule biopsy of the small intestine. F Pediatr Gastroenterol Nutr 1988;7:544-7.

12 Gilman RH, Miranda E, Marquis GS, Vestegui M, Martinez $H$. Rapid reinfection by Giardia lamblia after treatment in a hyperendemic third world community. Lancet 1988;i: 343-5.

13 Sullivan PB, Marsh MN, Mirakian R, Hill SM, Milla RJ, Neale G. Chronic diarrhoea and malnutrition-histology of the small intestinal lesion. 7 Pediatr Gastroenterol Nutr 1991 (in press).

14 Ament ME, Rubin CE. Relation of giardiasis to abnormal intestinal structure and function in gastrointestinal immunodeficiency syndromes. Gastroenterology 1972;62. immunode 216 .

15 Chandra RK, Puri S, Vyas D. Malnutrition and intestinal immunity. In: Marsh MN, ed. Immunopathology of the small immunity. In: Marsh MN, ed. Immunopatholo

16 Roberts-Thompson IC, Mitchell GF. Giardiasis in mice. I. Prolonged infections in certain mouse strains and hypothymic (nude) mice. Gastroenterology 1978;75:42-6.

17 Viteri FE, Schneider RE. Gastrointestinal alterations in protein-calorie malnutrition. Med Clin North Am 1974;58 1487-505.

18 Haas $\mathrm{J}$, Bucken EW. Zum krankheitswest der lamblieninfektion. Dtsch Med Wochenschr 1967;92:1869-71.

19 Sullivan PB, Thomas JE, Wight DGD, et al. Helicobacter pylori in Gambian children with chronic diarrhoea and malnutrition. Arch Dis Child 1990;65:189-91.

20 Morris A, Nicholson G. Ingestion of Campylobacter pyloridis causes gastritis and raised fasting gastric pH. Am $\mathcal{J}$ causes gastritis and raised
Gastroenterol 1987;82:192-9.

21 Rowland MGM. Epidemiology of diarrhea in The Gambia. In: Chen LC, Scrimshaw NS, eds. Diarrhea and malnutriIn: Chen LC, Scrimshaw NS, eds. Diarrhea and malnutrition:interactions, mechanisms and
Plenum Publishing, 1982:87-98.

The wonderful world of MRI

Just as we've got used to the beautiful anatomy textbook pictures of conventional magnetic resonance imaging (MRI) we're back in an amazing Walt Disney world with magnetic resonance angiography (MRA). Witznitzer and his colleagues in Cleveland, Ohio (Fournal of Pediatrics 1990; 117: 551-5) studied 10 children with sickle cell disease and cerebrovascular problems using MRI of the brain and non-invasive MRA. The moving blood gives a stronger signal and by adjusting the sensitivity the surrounding brain signals can be eliminated leaving a picture of the major vessels. For connoisseurs the name of the game is three dimensional Fourier transform time of flight MRA. Despite all that the pictures are very exciting, showing the major arteries both in the neck and inside the head and clearly demonstrating vessel occlusions. The technique will obviously be extremely useful for investigating cerebral vascular disease of all kinds in children and not only that due to sickle cell disease, and it offers a prospect of advancing our understanding of much cerebral pathology.

Now that access to computed tomography is much easier for many of us it looks as if we may well have to start rattling the can for more MRI scanners. And nary a needle need go near the child. Gee, Pinocchio, ain't that wunnerful! 